GÜTERSLOHER

VERLAGSHAUS

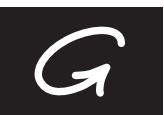

Gütersloher Verlagshaus. Dem Leben vertrauen 


\section{Archive for Reformation History}

An international journal concerned with the history of the Reformation and its significance in world affairs, published under the auspices of the Verein für Reformationsgeschichte and the Society for Reformation Research

\section{Board of Editors}

Jodi Bilinkoff, Greensboro/North Carolina - Gérald Chaix, Tours - David Cressy, Columbus/Ohio - Michael Driedger, St. Catharines/Ontario - Mark Greengrass, Sheffield - Scott Hendrix, Princeton/New Jersey - Mack P. Holt, Fairfax/Virginia Susan C. Karant-Nunn, Tucson/Arizona - Thomas Kaufmann, Göttingen - Ernst Koch, Leipzig - Janusz Małłek, Toruń - Silvana Seidel Menchi, Pisa - Bernd Moeller, Göttingen - Carla Rahn Phillips, Minneapolis/Minnesota - Heinz Scheible, Heidelberg - Heinz Schilling, Berlin - Anne Jacobson Schutte, Charlottesville/Virginia - Christoph Strohm, Heidelberg - James D. Tracy, Minneapolis/Minnesota

North American Managing Editors

Susan C. Karant-Nunn - Anne Jacobson Schutte

European Managing Editor

Heinz Schilling

Vol. $101 \cdot 2010$ 


\section{Archiv für Reformationsgeschichte}

Internationale Zeitschrift zur Erforschung der Reformation und ihrer Weltwirkungen, herausgegeben im Auftrag des Vereins für Reformationsgeschichte und der Society for Reformation Research

\section{Herausgeber}

Jodi Bilinkoff, Greensboro/North Carolina - Gérald Chaix, Tours - David Cressy, Columbus/Ohio - Michael Driedger, St. Catharines/Ontario - Mark Greengrass, Sheffield - Scott Hendrix, Princeton/New Jersey - Mack P. Holt, Fairfax/Virginia Susan C. Karant-Nunn, Tucson/Arizona - Thomas Kaufmann, Göttingen - Ernst Koch, Leipzig - Janusz Małłek, Toruń - Silvana Seidel Menchi, Pisa - Bernd Moeller, Göttingen - Carla Rahn Phillips, Minneapolis/Minnesota - Heinz Scheible, Heidelberg - Heinz Schilling, Berlin - Anne Jacobson Schutte, Charlottesville/Virginia - Christoph Strohm, Heidelberg - James D. Tracy, Minneapolis/Minnesota

Europäische Redaktion

Heinz Schilling

Nordamerikanische Redaktion

Susan C. Karant-Nunn - Anne Jacobson Schutte

Vol. $101 \cdot 2010$ 


\author{
Mitarbeiter der Redaktion - Editorial Assistant \\ Christian Jaser, M.A. \\ Humboldt-Universität zu Berlin \\ Institut für Geschichtswissenschaften
}

Das Archiv für Reformationsgeschichte erscheint jährlich in einem normalerweise 320 Seiten umfassenden Aufsatzband und einem ca. 192 Seiten umfassenden Literaturbericht (Beiheft).

Manuskripte aus Europa werden erbeten an Prof. Dr. Dr.h.c. Heinz Schilling, Institut für Geschichtswissenschaften, Humboldt-Universität zu Berlin, Unter den Linden 6, D-10099 Berlin. Manuskripte aus Nordamerika werden als E-Mail-Sendungen erbeten an Prof. Dr. Randall C. Zachman, rzachman@nd.edu (Postadresse: 130 Malloy Hall, University of Notre Dame, Notre Dame, IN 46556, USA). Es werden nur Original-Beiträge aufgenommen. Es wird empfohlen, rechtzeitig vor Abschluß des Manuskripts bei der jeweiligen Redaktion Merkblätter zur formalen Gestaltung der Beiträge anzufordern. Besprechungsexemplare aus Europa und Nordamerika werden erbeten an Prof. Dr. Markus Wriedt, Institut für Europäische Geschichte, Abteilung für Abendländische Religionsgeschichte, Alte Universitätsstraße 19, D-55116 Mainz.

The Archive for Reformation History appears annually in one volume consisting usually of 320 pages containing the essays and a supplement volume consisting of 192 pages containing the literature review.

Manuscripts and communications concerning editorial matters originating in North America should be sent by e-mail to Prof. Dr. Randall C. Zachman, rzachman@nd.edu. His postal address is 130 Malloy Hall, University of Notre Dame, Notre Dame, IN 46556, USA. Manuscripts and communications originating in Europe should be sent to Prof. Dr. Dr. h.c. Heinz Schilling, Institut für Geschichtswissenschaften, Humboldt-Universität zu Berlin, Unter den Linden 6, 10099 Berlin, Germany. Only original manuscripts are accepted. Authors' guides for the preparation of manuscripts are available from either the North American or the European managing editors. Books, journal articles, and offprints for review originating in North America or Europe should be sent to Prof. Dr. Markus Wriedt, Institut für Europäische Geschichte, Abteilung für Abendländische Religionsgeschichte, Alte Universitätsstraße 19, 55116 Mainz, Germany.

ISBN 978-3-579-08458-9

ISSN 0003-9381

Copyright (C) 2010 by Gütersloher Verlagshaus, Gütersloh, in der Verlagsgruppe Random House GmbH, München

Die Zeitschrift und alle in ihr enthaltenen einzelnen Beiträge und Abbildungen sind urheberrechtlich geschützt. Jede Verwertung außerhalb der engen Grenzen des Urheberrechtsgesetzes ist ohne Zustimmung des Verlages unzulässig und strafbar. Das gilt insbesondere für Vervielfältigungen, Übersetzungen, Mikroverfilmungen und die Einspeicherung und Verarbeitung in elektronischen Systemen.

Satz: SatzWeise, Föhren

Druck und Einband: Hubert \& Co., Göttingen

Printed in Germany

www.gtvh.de 


\section{Inhalt}

Wim François: The Antwerp Printers Christoffel and Hans (I) van Ruremund, Their Dutch and English Bibles, and the Intervention of the Authorities in the 1520s and 1530s . . . . . . . . . . . . . . .

Ruth Slenczka: Die Stadt als Bild der Verheißung. Minden auf dem Bildnis des Superintendenten Hermann Huddäus von Ludger tom Ring dem Jüngeren von 1568 . . . . . . . . . . . . . . . . . .

David M. Luebke: Confessions of the Dead. Interpreting Burial Practice in the Late Reformation . . . . . . . . . . . . . .

Carrie Euler: Does Faith Translate? Tudor Translations of Martin Luther and the Doctrine of Justification by Faith . . . . . . . . . . . . . . . .

Alec Ryrie: The Psalms and Confrontation in English and Scottish Protestantism .

Robert von Friedeburg: Ecclesiology and the English State. Luther and Melanchthon on the Independence of the Church in English Translations of the 1570s

Patrick J. O'Banion: For the Defense of the Faith? The Crusading Indulgence in Early Modern Spain . . . . . . . . . . . . . . .

Simon Ditchfield: Decentering the Catholic Reformation. Papacy and Peoples in the Early Modern World . . . . . . . . . . . . . . . . . . .

Rady Roldan-Figueroa: Father Luis Piñeiro, S.J., the Tridentine Economy of Relics, and the Defense of the Jesuit Missionary Enterprise in Tokugawa Japan . . .

Themenschwerpunkt / Focal Point: The Protestant Reformation and the Middle Ages . . . . . . . . . . . . . . . .

Mark Greengrass, Matthias Pohlig: Preface

Harald Bollbuck: Testimony of True Faith and the Ruler's Mission. The Middle Ages in the Magdeburg Centuries and the Melanchthon School . . . . . . .

Matthias Pohlig: Matthias Flacius, Simon Goulart and the Catalogus testium veritatis: Protestant Historiography in an Age of inner-Protestant Struggle . . . .

Mark Greengrass, Matthew Phillpott: John Bale, John Foxe and the Reformation of the English Past . . . . . . . . . . . . . . . . . . .

Irena Backus: What is a Historical Account? Religious Biography and the Reformation's break with the Middle Ages 
Buchbesprechungen / Reviews . . . . . . . . . . . . . . 305

Thomas Kaufmann: „History is good at confounding and confessing labelers“ „Die Geschichte versteht es meisterlich, Schlagwortexperten zu irritieren und zu verwirren“. Zu Diarmaid MacCullochs „Reformation“ . . . . . . . . . 305

Horst Dreier: Rechte Konfession - Konfession im Recht. Rezension zu: Christoph Strohm, Calvinismus und Recht. Weltanschaulich-konfessionelle Aspekte im Werk reformierter Juristen in der Frühen Neuzeit ． . . . . . . . . . . 321 


\title{
The Antwerp Printers Christoffel and Hans (I) van Ruremund, Their Dutch and English Bibles, and the Intervention of the Authorities in the 1520s and 1530 s* $^{*}$
}

\author{
By Wim François
}

\section{VERNACULAR BIBLE READING AND CENSORSHIP IN ENGLAND AND THE LOW COUNTRIES}

At the beginning of the 16th century, European church authorities had no unequivocal policy on the translation of the Bible into the vernacular. In several different European countries and regions, the religious evolutions of the late Middle Ages had inspired the authorities' attitude towards the vernacular Bible. Spiritual reform movements that had arisen in different parts of Europe - especially in the second half of the 14th century - had also inspired a desire to read the Scriptures among laypeople as a source of spiritual nourishment. The inclination towards do-it-yourself spiritual advancement was even greater where the clergy had failed in their pastoral duties. ${ }^{1}$ In several places in Europe, the said reform movements even crossed the line between orthodoxy and heresy. The condemnation of the movement associated with John Wyclif (c. 1320-1384), for example, also discredited the 'Lollard Bibles' which had started to circulate

\footnotetext{
* An earlier draft of this essay had been presented at the International Conference on Authority in European Book Culture 1400-1600, 29 June-1 July 2006, Liverpool (UK). I wish to thank Mr. Eric Van Pee and my colleague, Prof. Brian Doyle, for their invaluable assistance in translating this text. - Abbreviations: DM Rev: Arthur Sumner Herbert, Historical Catalogue of Printed Editions of the English Bible, 1525-1961: Revised and Expanded from the Edition of T. $H$. Darlow and H. F. Moule, 1903, London, New York 1968; BS: www.bibliasacra.com [a digital bibliography of Bibles printed in the Netherlands and in Belgium - 1477-1553]; NK: Wouter Nijhoff, Maria Elizabeth Kronenberg, Nederlandse bibliographie van 1500 tot 1540, 3 vols., 's Gravenhage 1923-1971; STC: Alfred William Pollard, Gilbert Richard Redgrave, A Short-title Catalogue of Books Printed in England, Scotland, and Ireland and of English Books Printed Abroad, 1475-1640, 2nd ed., rev. and enl., begun by W. A. Jackson, F. S. Ferguson, compl. by Katharine F. Pantzer, 3 vols., London 1976-1991.

1. For a general introduction into the topic, see also Klaus Schreiner, "Volkstümliche Bibelmagie und volkssprachliche Bibellektüre. Theologische und soziale Probleme mittelalterlicher Laienfrömmigkeit," in: Peter Dinzelbacher, Dieter R. Bauer (eds.), Volksreligion in hohen und späten Mittelalter, Paderborn 1990, pp. 329-373, esp. 353-364.
} 
in England in his wake. ${ }^{2}$ The Oxford Synod of 1407-1409 convened by Archbishop Thomas Arundel issued the so-called Oxford Constitutions, which forbade any translation of the Bible into English or another vernacular language without the prior approval of the local bishop or a provincial council. ${ }^{3}$

In the Low Countries, the influence of the Devotio Moderna had spread from the middle of the 1370s onwards. In this milieu, the reading of the Scripture in the vernacular was propagated as being beneficial to one's spiritual life. ${ }^{4}$ One of the most important initiators of the Devotio Moderna was Geert Grote (13401384) who was himself responsible for the translation of several of the Psalms into Dutch. Around 1390, Johan Schutken, librarian at the monastery of Windesheim, made available a Dutch version of the New Testament and of the pericopes taken from the Old Testament that were read during mass. A few years later, another leading figure of the Devotio Moderna, the canonist and librarian of the house of the Brethren of the Common Life in Deventer, Gerard Zerbolt of Zutphen, wrote several tracts defending the reading of the vernacular Bible by laici spirituales..$^{5}$ Zerbolt's action was evidently successful, given the official approval of the

2. On John Wyclif and the so-called 'Lollard' Bibles, see the works of Anne Hudson, especially: Anne Hudson, The Premature Reformation: Wycliffite Texts and Lollard History, Oxford 1988, pp. 228-277, esp. 228-247, and Mary Dove, The First English Bible: The Text and Context of the Wycliffite Versions, Cambridge 2007. Also: Gustav Adolf Benrath, "John Wyclif. Doctor evangelicus," in: Ulrich Köpf (ed.), Theologen des Mittelalters. Eine Einführung, Darmstadt 2002, pp. 197-211.

3. David Wilkins (ed.), Concilia Magnae Britanniae et Hiberniae ... constitutiones..., 4 vols., London: R. Gosling, F. Gyles, T. Woodward, C. Davis, 1737; anast. repr., Brussels 1964, 3, c. 314-319, esp. 317. For a discussion of the censura, see, for example, Anne Hudson, Lollards and their Books, London, Ronceverte 1985, pp. 67-84, and 147-148; Nicholas Watson, "Censorship and Cultural Change in Late Medieval England: Vernacular Theology, the Oxford Translation Debate, and Arundel's Constitutions of 1409," in: Speculum 70 (1995), pp. 822-864; Kantik Gosh, The Wycliffite Heresy: Authority and the Interpretation of Texts, Cambridge 2002, pp. 86-111.

4. About Middle Dutch Bible translations in general and the Devotio Moderna in particular, see Sabrina Corbellini, "De Noordnederlandse vertaling van het Nieuwe Testament. Het paradijs in een kloostercel," in: August den Hollander, Eric Kwakkel, Wybren Scheepsma (eds.), Middelnederlandse bijbelvertalingen, Hilversum 2007, pp. 131-145. See also: Geert H. M. Claassens, "Bible Translations, Dutch," in: John M. Jeep (ed.), Medieval Germany. An Encyclopedia, New York, London 2001, pp. 59-61.

5. About G. Zerbolt van Zutphen and the apologia of the lay Bible, see, particularly, Nikolaus Staubach, "Gerhard Zerbolt von Zutphen und die Apologie der Laienlektüre in der Devotio moderna," in: Thomas Kock, Rita Schlusemann (eds.), Laienlektüre und Buchmarkt im späten Mittelalter, Frankfurt/M. 1997, pp. 221-289. See also: Volker Honemann, "Der Laie als Leser," in: Klaus Schreiner, Elisa Müller-Luckner (eds.), Laienfrömmigkeit im späten Mittelalter. Formen, Funktionen, politisch-soziale Zusammenhänge, München 1992, pp. 241-251. 
way of life of the Brethren and Sisters of the Common Life in 1401 by Frederick of Blankenheim (bishop of Utrecht), including the reading of the Scriptures in the vernacular language (under the condition, of course, that the translations did not contain heresies, that they were in accordance with the doctrines and formulations of the Church, and that the readers were prepared to let themselves be instructed by learned men). ${ }^{6}$ In short, unlike John Wyclif's movement, the Devotio Moderna remained within the Church and vernacular Bibles were regarded for the most part as non-heretical. In addition, vernacular Bibles were not confined to the (semi-)religious communities rooted in the spirituality of the Devotio Moderna, but also found their way into the hands of literate lay people in the world'.

Such was the situation at the beginning of the 16th century when humanists and reformers set out to establish the Bible once again as the basis for a reform of the Church and encouraged its reading by laypeople. Erasmus supported this idea, and although he himself never endeavoured to make his own translation into the vernacular, his Latin-Greek editions of the New Testament, which were published after 1516, were used extensively for vernacular Bible versions. Luther published his German translation of the New Testament - the so-called 'September Testament' - in 1522, after which he set about a translation of the Old Testament (which was published in several phases until the entire Luther Bible was finished in 1534). In the Low Countries, anonymous translators made Dutch versions of Luther's New Testament. The Antwerp printer-publisher Adriaen van Berghen released an edition of the New Testament in 1523, the Gospels, the Acts of the Apostles and the Book of Revelation of which were based upon Luther's New Testament. In the edition published later that year by his Amsterdam colleague Doen Pietersoen, the Epistles also were translated from Luther's Bible. The 1523 Dutch translation published by Van Berghen - Pietersoen was to serve for many years as the basis for further editions of the Dutch New Testament. In 1524, a Dutch translation of Erasmus's Novum Testamentum left the presses of the Delft printer-publisher Cornelis Henricsz Lettersnijder, the translator of which was also unknown. ${ }^{7}$

6. Paul Fredericq (ed.), Corpus documentorum Inquisitionis haereticae pravitatis Neerlandicae. Verzameling van stukken betreffende de pauselijke en bisschoppelijke Inquisitie in de Nederlanden, 5 vols., Gent, 's Gravenhage 1889-1903, 2, pp. 190-193, esp. 192.

7. On Dutch translations in the Early Modern Period, see especially August den Hollander, De Nederlandse bijbelvertalingen. Dutch Translations of the Bible 1522-1545, Nieuwkoop 1997, and also Cebus C. de Bruin, De Statenbijbel en zijn voorgangers: Nederlandse bijbelvertalingen vanaf de Reformatie tot 1637, 2nd ed., rev. by Frits G. M. Broeyer, Haarlem, Brussels 1993, pp. 63-149. See also www.bibliasacra.com, accessed on January 15th 2009. For an in- 
For his part, William Tyndale released his English translation of the New Testament in 1526. His work was based on the Greek text of Erasmus' Novum Testamentum (the third edition, from 1522) and was also inspired by Luther's New Testament (the third edition, from 1524). An attempt to have his translation printed by Peter Quentell in Cologne was interrupted by Johann Cochlaeus in 1525 . At this stage he had only managed to have printed a prologue and a translation of the text up to Matthew 22, albeit provided with Lutheran-minded marginal glosses. A year later, in 1526, he managed to publish his (first) complete English translation of the New Testament in octavo format at Peter Schoeffer's in Worms. The prologue and glosses had been removed. ${ }^{8}$

\section{CHRISTOFFEL VAN RUREMUND'S ENGLISH TYNDALE BIBLES AND THE AUTHORITIES' INTERVENTIONS}

In the same year, 1526, the Antwerp printer Christoffel van Ruremund, also known as Christoffel van Endhoven $(\dagger 1531)^{9}$ issued his first (pirate) version of Tyndale's New Testament. In line with several other continental printers who were technically more advanced than their thinly spread English colleagues, Van Ruremund had already been producing works for the flourishing English

troduction into the topic, see also Wim François, "Die volkssprachliche Bibel in den Niederlanden des 16. Jahrhunderts. Zwischen Antwerpener Buchdruckern und Löwener Buchzensoren," in: Zeitschrift für Kirchengeschichte 108 (2009), pp. 187-214

8. On William Tyndale and his Bible translations, see, for example, David Daniell, William Tyndale: A Biography, New Haven, CT, London 1994, pp. 108-111, 142-145, 169; id., The Bible in English: Its History and Influence, New Haven, CT, London 2003, pp. 133-159, esp. 143-146. A good summary is to be found in id., "William Tyndale, the English Bible, and the English Language," in: Orlaith O'Sullivan, Ellen N. Herron (eds.), The Bible as Book: The Reformation, St. Pancras, New Castle, DE 2000, pp. 39-50; Guido Latré, "William Tyndale: Reformer of a Culture, Preserver of a Language, Translator for the Ploughboy," in: Paul Arblaster, Gergely Juhász, Guido Latré (eds.), Tyndale’s Testament, Turnhout 2002, pp. 11-24; Gwendolyn Verbraak, "William Tyndale and the Clandestine Book Trade: A Bibliographical Quest for the Printers of Tyndale's New Testaments," in: Wim François, August den Hollander (eds.), Infant Milk or Hardy Nourishment? The Bible for Lay People and Theologians in the Early Modern Period, Leuven 2009, pp. 167-189. Cf. also: Heinz Holeczek, Humanistische Bibelphilologie als Reformproblem bei Erasmus von Rotterdam. Thomas More und William Tyndale, Leiden 1975, pp. 246-278.

9. On Christoffel van Ruremund and his printing activities, see Anne Rouzet (ed.), Dictionnaire des imprimeurs, libraires et éditeurs des XVe et XVIe siècles dans les limites géographiques de la Belgique, Nieuwkoop 1975, pp. 193-194; de Bruin, Broeyer, De Statenbijbel (as in note 7), pp. 84-85; den Hollander, De Nederlandse bijbelvertalingen (as in note 7), pp. 68-71. 
market for several years. He specialised in printing liturgical books according to the Sarum rite (the rite followed in the so-called Church of Salisbury and a large part of England). ${ }^{10}$ In contrast to the Worms edition, Christoffel van Ruremund's pirate version of Tyndale's New Testament was probably a hastily printed sextodecimo.

The English government was very apprehensive with respect to the import of 'heretical' books and New Testaments, and works of this sort were immediately burned if intercepted. ${ }^{11}$ John Hackett, King Henry VIII's 'ambassador' in the Low Countries (in addition to his activities as trade commissioner in Antwerp), must certainly have known about the production of these New Testaments, which he undoubtedly considered illegal. ${ }^{12}$ As early as November 1526 , he notified the English Cardinal Thomas Wolsey of the smuggling of "thys nywe impryntyd bokes," alluding to the Tyndale Bibles (and possibly other heretical literature) stemming from the Low Countries. With London's blessing, Hackett was to try as hard as he could to stop this illegal trade in several places. Aligning himself with the official opinion, he labelled the reading of the Bible in the vernacular a source of heresy, since, as he added, "every fooll wold tynck to be a doctor." In November 1526, Hackett first appealed to the 'Governor(s) of the Merchant Adventurers' ${ }^{13}$ who were compelled to warn the English merchants trading at the annual fairs of Bergen op Zoom - in this period the so-called 'cold market' which started in November 'after All Hallows' - that these New Testa-

10. On the activities of Antwerp printers - and the brothers Van Ruremund in particular on the English market: Frederick C. Avis, "England's Use of Antwerp Printers 1500-1540," in: Hans Widmann (ed.), Gutenberg-Jahrbuch 1973, Mainz 1973, pp. 234-240, esp. 234-235, 239; Elizabeth Armstrong, "English Purchases of Printed Books from the Continent 14651526," in: The English Historical Review 94 (1979), pp. 268-290, esp. 288; Francine de Nave, "Antwerpen, dissident drukkerscentrum in de 16de eeuw: algemene synthese," in: Dirk Imhof, Gilbert Tournoy, Francine de Nave (eds.), Antwerpen, dissident drukkerscentrum. De rol van de Antwerpse drukkers in de godsdienststrijd in Engeland (16de eeuw), Antwerp 1994, pp. 13-21, esp. 15-16.

11. Cf. Franz Heinrich Reusch, Der Index der Verbotenen Bücher: Ein Beitrag zur Kirchenund Literaturgeschichte, 2 vols., Bonn 1883-1885, 1, pp. 88-93.

12. On the correspondence of John Hackett: Elizabeth Frances Rogers (ed.), The Letters of Sir John Hackett 1526-1534, Morgantown, WV 1971. On Hackett's attempts to prevent the smuggle of English New Testaments: Elizabeth Frances Rogers, "Sir John Hackett, Henry VIII's Ambassador in Malines," in: Medievalia et Humanistica 6 (1950), pp. 89-100, esp. 93-95; Oskar De Smedt, De Engelse Natie te Antwerpen in de 16de eeuw (1496-1582), 2 vols., Antwerp 1950-1954, 2, pp. 605-607.

13. It is not very clear who was (or were) the governor(s) at that moment. Officially, it was a duumvirate consisting of John Park and Paul Whetipoll, but it is not certain whether John Park took up the office (De Smedt, ibid., 2, pp. 54-55, 76, 89). 
ments were considered absolutely illegal in their home country. ${ }^{14}$ Hackett also went to Malines to solicit the support of Governess Margaret of Austria and her Privy Council in his ongoing endeavour to stop the trade in 'heretical' works. ${ }^{15}$ In Antwerp, Hackett made a personal investigation into the source of the forbidden New Testaments to determine where they were being printed and sold. On November 24th 1526, he was able to send Wolsey two copies of these Bibles, and inform the cardinal that two Antwerp printers had provided them. There can be little doubt that the publishers in question were Christoffel and his brother Hans (I) van Ruremund. ${ }^{16}$ Hackett thought the time had come to take legal action. Through Jean Carandolet, archbishop of Palermo and president of the Privy Council, he informed Margaret of Austria of the situation and she, for her part, urged the margrave of Antwerp to take prompt measures. Hackett also personally contacted the margrave himself. The English ambassador thus seemed quite sure that measures would be taken without delay: the forbidden New Testaments would be burned - the same punishment as in England - and the Antwerp prin-

14. On the Fellowship of English Merchant Adventurers in Antwerp and its activities at the four annual fairs of Brabant (Bergen op Zoom and Antwerp): De Smedt, De Engelse Natie (as in note 12$), 1$, pp. 84-85, 127-137.

15. J. Hackett to Th. Wolsey, November 21st 1526, in: Rogers (ed.), Letters (as in note 12), n 23 = Letters and Papers, vol. IV (henceforth: L.P. IV.), 2649, p. 42. See also: Rogers, "Sir John Hackett" (as in note 12), p. 93.

16. P. J. A. Fransen, followed to some degree by F. de Nave, has recently suggested that the trade in books between the Low Countries and England had been illegal since 1526. It was due for the most part to the smuggle of Tyndale Bibles by - among others - the Van Ruremund brothers, that the English authorities are thought to have seriously restricted the import of books, if not totally put a stop to it (Peter J. A. Franssen, "Jan van Doesborch's Departure from Antwerp and His Influence on the Utrecht Printer Jan Berntsz," in: Quaerendo 18 [1988], pp. 163-190, esp. 167; id., Tussen tekst en publiek, Jan van Doesborch, drukker-uitgever en literator te Antwerpen en Utrecht in de eerste helft van de zestiende eeuw, Amsterdam, Atlanta, GA 1990, p. 23; de Nave, "Antwerpen" [as in note 10], p. 16). The authors probably draw too radical conclusions from the aforementioned article: Armstrong, "English Purchases" (as in note 10), p. 290. Armstrong only states that the English government reacted with heightened watchfulness and censorship measures to the illegal import of Tyndale Bibles. The legal trade in books between the continent and England was certainly impeded in 1526, but not stopped. This can be deduced from the survey in Avis, "England's Use" (as in note 10), pp. 235-239. It was only on Christmas Day 1534 that Henry VIII withdrew the special privileges granted to printers by the law of 1484 and imposed restrictions on the importation of books. This was to protect the English printers, who were now capable of printing the books needed in their own country, and presumably also to suppress the importation of controversial works (David M. Loades, "Le livre et la Réforme anglaise avant 1558," in: Jean-François Gilmont [ed.], La Réforme et le livre: l'Europe de l'imprimé [1517-v.1570], Paris 1990, pp. 269-300, esp. 275 and 293). 
ters involved would be prohibited from placing them on the market. ${ }^{17}$ The Antwerp magistrates, however, were reluctant to take measures against their subjects on nothing more than the request of the English authorities and they were particularly on their guard against disturbing the economically important printers' business. On the occasion of a meeting at the Governess's court, the city magistrates argued that the local judges wanted to assess the nature of the offence for themselves. To this end they proposed that the said New Testament editions be translated into Dutch or Latin (which, given the nature of the book, sounds rather pointless) and that copies of the New Testaments be sent from England for the purpose. ${ }^{18}$ Hackett managed to secure a number of copies in a shipment that also contained a warning penned by Bishop Cuthbert Tunstall of London, cautioning that the books in question contained errors and heresies. Hackett took the material to the court of Malines in early 1527 and Margaret of Austria immediately wrote a letter to the Antwerp margrave and city council demanding that measures to be taken. Hackett himself delivered the Governess' letter to the assembled Antwerp authorities, together with copies of the New Testaments that had been condemned and burned in England. ${ }^{19}$ The margrave promised Hackett that he would make a final decision on the measures to be taken within three or four days. On January 12th 1527, Hackett was able to report to Wolsey that the margrave intended to have the prohibited editions burned, Christoffel van Ruremund exiled and a third of his possessions confiscated. The English ambassador added that these measures were to be based upon the most recent imperial edict. ${ }^{20}$ Apparently, Christoffel van Ruremund was indeed arrested and locked up in prison (together with another printer, who proved to be innocent). Christoffel van Ruremund's attorney maintained, however, that the Emperor's subjects

17. J. Hackett to Th. Wolsey, November 24th 1526, in Rogers (ed.): n 24 = L.P. IV. 2652, pp. 45-46. Also: Rogers, "Sir John Hackett" (as in note 12), pp. 93-94, and E. Gordon Duff, $A$ Century of the English Book Trade: Short Notices of all Printers, Stationers, Book-binders and Others Connected with it from the Issue of the First Dated Book in 1457 to the Incorporation of the Company of Stationers in 1557, London 1905, p. 140.

18. J. Hackett to Th. Wolsey, December 22nd 1526, in: Rogers (ed.), Letters (as in note 12), n 29 = L.P. IV. 2721, pp. 57-59. See also: Rogers, "Sir John Hackett" (as in note 12), p. 94.

19. J. Hackett to B. Tuke, January 4th 1527, in: Rogers (ed.), Letters (as in note 12), n $30=$ L.P. IV. 2778, p. 59. See also: Roger, "Sir John Hackett" (as in note 12), p. 94.

20. "(...) the Inprimer off the sayd bookes namyd Christofer Endhowe[n] ought to be banyshyd owte off all the Emperoris landes and contres and that $t[$ he] tyrd part off all hys goodes showld be confyskyd in the Emperor in han[des] and all the forsayd Englyshe bookes bowrnt to the fyre (...)" (Hackett to Th. Wolsey, January 12th 1527, in: Rogers [ed.], Letters (as in note 12$)$, n 31 = L.P. IV. 2797, p. 65). 
could not be judged according to the laws of another country. He also denied that any heresies were included in the English books printed by Christoffel van Ruremund and he challenged the margrave to pinpoint the articles containing errors or heresies. The Antwerp judges appear to have followed the plea of the attorney and insisted that the margrave first substantiate the accusation of heresy. As a consequence, the margrave had to abandon his case, no doubt because he as with the majority of people in the Low Countries in those days - did not have a sufficient command of the English language to scrutinize the Bible's contents. John Hackett, for his part, immediately went to Malines to complain to the Governess about this "denegacion of iustyce," after which he also had a very frank discussion with the Privy Council. ${ }^{21}$ In the same report to Wolsey dated January 12th 1527 and written shortly after the conclusion of the legal proceedings, John Hackett expressed his considerable dissatisfaction with the course of events. He even considered the possibility of buying up all the forbidden New Testaments himself and shipping them to Wolsey for burning.

As already noted, Hackett did not only try to shut down trade in New Testaments at their production centre in Antwerp, but also at the annual fairs of Bergen op Zoom where English merchants were actively doing business. As required, the 'Governor(s) of the Merchant Adventurers' had promulgated the letters of the English king to his fellow countrymen and merchants in Bergen op Zoom. Hackett for his part had written a letter to the Lord of Bergen op Zoom, calling for "the extyrpacion off the abhomynable secte Luterian" and insisting on judicial action against any English New Testaments being offered at the fairs. According to the ambassador, this request enjoyed the support of the 'Governor', who was able to provide ample illustration of the detrimental effects of such trade. Hackett hoped to evaluate the situation in Bergen op Zoom as soon as the Antwerp matters had been settled by the local authorities. ${ }^{22}$

A few days later, on January 16th 1527, the Antwerp authorities did indeed take legal measures to curb further production and trade in the contested English Tyndale Bibles. The Antwerp schout [sheriff] Claes van Lyere and the city Magistrate promulgated an edict prohibiting the possession of English New Testaments, demanding that existing copies be handed over to the authorities within

21. J. Hackett to Th. Wolsey, January 12th 1527, in: Rogers (ed.), Letters (as in note 12), n 31 = L.P. IV. 2797, pp. 63-68. See also: Rogers, "Sir John Hackett" (as in note 12), pp. 9495. Rogers' suggestion that John Clifford or John Stile was the Governor is obviously not attested by the sources (cf. supra, n. 13). Cf. also: Duff, A Century (as in note 17), p. 140.

22. J. Hackett to Th. Wolsey, January 12th 1527, in: Rogers (ed.), Letters (as in note 12), n 31 = L.P. IV. 2797, pp. 68-69. See also: Rogers, "Sir John Hackett" (as in note 12), pp. 9495; Duff, $A$ Century (as in note 17), p. 140. 
eight days in order to be burned. The Antwerp city Magistrate explicitly aligned itself with the measures in force in England and those who refused to obey were to be "scherpelyc gecorrigeert" [severely punished]. ${ }^{23}$ The actual meaning of the phrase was - probably intentionally - left open (in fact, it could be seen to imply severe punishment, whipping, mutilation or even public execution). ${ }^{24}$ No more mention was made of banishment or confiscation of a third of the goods, a punishment that John Hackett had had in mind. The edict's stipulations were probably the result of a compromise between several conflicting interests. On the one hand, the English government (for diplomatic reasons supported by the Governess and the Privy Council in Malines) were exerting pressure on the Antwerp city Magistrate intent on preventing trade in 'heretical' English New Testaments. At the same time, however, the Antwerp magistrates were reluctant to subject their citizens to the laws of a foreign country or to upset the economically important printing industry. This is an example of how censorship in the Early Modern Era was not the simple enforcement of a prevailing rule, but the result of negotiations whereby the parties implied tried to assert their respective rights as much as possible. That in the case at hand the Antwerp city Magistrate did promulgate a clear prohibition on English New Testament editions, was due to the pressure exerted by the Governess and the Privy Council in the Low Countries, who did not want to have the diplomatic relations with the British government troubled.

John Hackett appeared to be content, for the time being, with arrangements in Antwerp. A large number of 'heretical' Bibles were probably burned in the city, as was the case in Bergen op Zoom where Hackett went afterwards. In spite of this, he was unable to prevent a group of Scottish merchants embarking from Zealand with a consignment of Tyndale Bibles for distribution in Edinburgh and St. Andrews. He was also forced once again to explain to Thomas Wolsey that the Antwerp margrave and the drossard (bailiff) of Bergen op Zoom continued to insist that concrete 'heretical' passages be selected from the contested books and be passed on to them for evaluation. Only then would it be possible not only to burn the books, but also to punish the printers, buyers and sellers thereof "in [both] their body and goods." 25

The illegal production and trade of English New Testaments, however, had not come to an end ... At the end of May 1527, Hackett informed Wolsey yet

23. Fredericq (ed.), Corpus (as in note 6), 5, pp. 184-185.

24. Cf. Latré, "William Tyndale" (as in note 8), p. 13.

25. J. Hackett to Th. Wolsey, February 20th 1527, in: Rogers (ed.), Letters (as in note 12), n 33 = L.P. IV. 2903, pp. 72-73, and J. Hackett to Th. Wolsey, February 20th 1527, in: Rogers (ed.), Letters (as in note 12), n 34 = L.P. IV. 2904, p. 77. See also: De Smedt, De Engelse Natie (as in note 12), 2, p. 606; Rogers, "Sir John Hackett", p. 95. 
again that Antwerp printers had brought copies of the English New Testament to be sold at the fair in Bergen op Zoom (this time the Easter market). Hackett was able to intercept a consignment of Bibles, managing to uncover no less than 24 copies in the possession of a single merchant, but he also repeated that the drossard of Bergen op Zoom and the Antwerp margrave still insisted that the English authorities provide articles from these biblical books containing clear proof of heresy. Only with these 'weapons' in hand, would it be possible to "boddelly" punish the perpetrators. In addition, Hackett continued, Tyndale Bibles had also been offered for sale at the Frankfurter Messe, then as now the centre of the international book trade. ${ }^{26}$

It remains clear, however, that Christoffel van Ruremund, his brother Hans (and perhaps other printers) persisted in illicitly exporting English New Testaments. Of the original 1526 pirate version (in sextodecimo format), Christoffel probably issued two reprints: one in 1530-31 (octavo?) and another around 1532-33 (quarto?). If this last edition did in fact leave the Van Ruremund presses, it must have been distributed by the widow of the printer, the latter having died in Westminster in 1531. ${ }^{27}$ Of these New Testaments, hundreds or even thousands of copies were illicitly shipped to London, hidden between the pages of more orthodox publications or between the folds of bales dried cloth, in spite of the efforts of the English authorities to stop the smuggling of illegal Bibles and burn intercepted copies. It is perhaps in part for this reason that no copies of Christoffel van Ruremund's three pirate versions (nor those of his brother Hans) have survived. ${ }^{28}$

Nonetheless, the English government still had a difficult time getting a grip on the import of Tyndale Bibles from Antwerp. A much cited report from 1529, for example, illustrates the desperation of Bishop Tunstall in face of this problematic situation. The latter apparently arranged a meeting with his agent in Antwerp, the merchant Augustine Packyngton, and heard from him that New Testaments were still being smuggled from the city to England. Realizing the

26. J. Hackett to Th. Wolsey, May 23rd 1527, in: Rogers (ed.), Letters (as in note 12), n 37 = L.P. IV. 3132, pp. 80-81.

27. Daniell, "William Tyndale" (as in note 8), p. 47; Gergely Juhász, "Catalogue n 102," in: Arblaster, Juhász, Latré (eds.), Tyndale’s Testament (as in note 8), pp. 159-160; Verbraak, "William Tyndale" (as in note 8), p. 170 and 179, with a reference to Wouter Nijhoff, Maria Elizabeth Kronenberg, Nederlandse bibliographie van 1500 tot 1540, 3 vols., 's Gravenhage 1923-1971, 3/inleiding, nos. 0170, 0171 and 0174.

28. De Smedt, De Engelse Natie (as in note 12), 2, p. 607; Andrew Hope, "On the Smuggling of Prohibited Books from Antwerp to England in the 1520s and 1530s," in: Arblaster, Juhász, Latré (eds.), Tyndale's Testament (as in note 8), pp. 35-40. 
ineffectiveness of his policy to burn 'heretic' Bibles (and other works) on arrival in England, Tunstall ordered Packyngton to go to Tyndale himself, buy the entire stock and burn the lot ... ${ }^{29}$

\section{CHRISTOFFEL VAN RUREMUND'S DUTCH BIBLE EDITIONS AND THE IMPERIAL 'BIBLE POLICY'}

In addition to his English Tyndale Bible, Christoffel van Ruremund also brought Dutch Bible editions onto the market. In 1525, he published a Dutch version of the Old Testament Book of Maccabees based upon the Vulgate. ${ }^{30} \mathrm{He}$ also published three Dutch editions of the New Testament in 1525, 1526 and 1528 , all of them based in one way or another on Luther's German translation. The 1525 New Testament edition (without the so-called 'epistle readings' - or 'first readings' read during mass - taken from the Old Testament), had a sextodecimo format and offered a 'mixed' text, drawn up on the basis of Luther and Erasmus editions. ${ }^{31}$ The text in question was taken from the 1525 edition printed in Antwerp by Merten de Keyser for Govaert van der Haeghen. The prologue is a translation of Luther's prologue to the 1522 New Testament. The Epistles and the Apocalypse are also preceded by Dutch translations of Luther's 1522 prefaces. A few marginal notes have been added, freely translated from those provided by Luther. Christoffel van Ruremund evidently took the precaution not to announce the notes and prologues on the title page.

According to the 1526 anti-heresy edict, editions of the Bible furnished with Reformation-minded glosses, summaries and/or prologues were strictly forbidden, although the edict in question did not impose an all-encompassing prohibition on vernacular Bibles. ${ }^{32}$ In probable reaction to this edict, Christoffel van

29. Edward Hall, Hall's Chronicle ... Collated with the Editions of 1548 and 1550, ed. Henry Ellis, London 1809; reprint, New York 1965, pp. 762-763. David Daniell, biographer and unconditional admirer of William Tyndale, insists: "It may well have happened: but not to Tyndale, who would never have agreed to sell New Testaments for public burning. It is more likely to have been a transaction with the Antwerp 'pirate' printer of Tyndale, Christopher Van Endhoven" (Daniell, The Bible in English [as in note 8], p. 145). Cf. Frederick Fyvie Bruce, History of the Bible in English, Cambridge 1961; reprint, 2002, pp. 37-39.

30. Den Hollander, De Nederlandse bijbelvertalingen (as in note 7), pp. 70, 309-310.

31. De Bruin, Broeyer, De Statenbijbel (as in note 7), pp. 84-85; den Hollander, De Nederlandse bijbelvertalingen (as in note 7), pp. 70, 221, 311-313.

32. On vernacular Bible editions and book censorship in the Low Countries, see, amongst others, Wim François, "Vernacular Bible Reading and Censorship in Early Sixteenth Century: The Position of the Louvain Theologians," in: August den Hollander, Mathijs Lamberigts 
Ruremund published another sextodecimo format edition of the New Testament in 1526, this time containing the passages of the Old Testament that were read during mass. ${ }^{33}$ The text is a translation of Luther's first edition of 1522, although some of the more pointed Reformation-minded sentences have been toned down or 'aligned' with the Vulgate. ${ }^{34}$ This 1526 Dutch Luther translation was to exert considerable influence and become the basic text of one of five genealogies or 'clusters' of Dutch Bible editions in the first decades of the sixteenth century. ${ }^{35}$ When compared with the 1525 edition, it appears that the 1526 New Testament also omits Luther's prologues and prefaces. Only a few marginal cross-references to other biblical passages remain, but there are no notes discussing the content. As a kind of alternative to the marginal notes - which were considered dangerous - an "onderwijs" [teaching] is included in the preliminary material. This represents what might be called a primary synoptic table, listing the texts of the different Gospels that could be compared with one another as well as those that were specific to one evangelist only. The tables in question ultimately relied on the canones, developed by the fourth century Bishop Eusebius of Caesarea, although still attributed in the sixteenth century to Ammonius Saccas. Bearing this in mind, the reassuring statement in the title of Van Ruremund's edition, "ghedruct sonder glosen, ende prologhen" [printed without glosses or prologues], is not entirely undeserved. At the end of the book, a "Tafel" [table] intend to help locate the Epistle and Gospel readings used during mass is included. In 1528, Christoffel van Ruremund published a (probably) unchanged edition of this New Testament. ${ }^{36}$ By omitting the dangerous 'paratextual' elements from his 1526 and 1528 editions, Christoffel van Ruremund acquiesced to some degree

(eds.), Lay Bibles in Europe. 1450-1800, Leuven 2006, pp. 69-96; id., "Die 'Ketzerplakate' Kaiser Karls in den Niederlanden und ihre Bedeutung für Bibelübersetzungen in den Volkssprache. Der 'Proto-Index' von 1529 als vorläufiger Endpunkt," in: Dutch Review of Church History 84 (2004), pp. 198-247.

33. De Bruin, Broeyer, De Statenbijbel (as in note 7), p. 111; den Hollander, De Nederlandse bijbelvertalingen (as in note 7), pp. 70, 225, 333-335.

34. Matt 3:2: "Hebt berou"; Matt 4:17: "Hebt berou”; Matt 16:18: "Ende ick segge u Ghi zyt Petrus ende op desen steen sal ick myn ghemeynte timmeren"; Rom 3:28: "Soo houden wy nu dat die mensche gherechtvaerdicht wort door tgheloove sonder die wercken des wets." The typically Lutheran term "alleen" [alone, here only], however, is not added to the word "tgheloove" [faith]. See also Jas 5:14: "Isser yemant cranck onder u die hale dye oudtste vander ghemeynten ende laet over hem bidden ende salven met olye (...)."

35. De Bruin, Broeyer, De Statenbijbel (as in note 7), p. 117; den Hollander, De Nederlandse bijbelvertalingen (as in note 7), p. 201.

36. De Bruin, Broeyer, De Statenbijbel (as in note 7), p. 111; den Hollander, De Nederlandse bijbelvertalingen (as in note 7), pp. 70, 225, 349. 
to the censorship activities of the authorities. The sextodecimo format of the editions, however, provides an indication of their intended public and the use that could be made of them. The little Bible books could easily be hidden in houses, but also in the broad sleeves of the garments commonly worn at the time. In this way they could be carried in secret to 'conventicles', clandestine meetings at which the Bible was read in the vernacular language and interpreted according to the new ideas.

In 1529, a severe anti-heresy edict was promulgated in the Low Countries, which also contained a kind of 'proto-index', probably drawn up by Louvain theologians. Bible editions from three printer-publishers were affected by the censure: those of Adriaen van Berghen, Christoffel van Ruremund and the mysterious 'Johannes Zel'. There can be little doubt that the editions in question were forbidden because the Louvain theologian-censors had noticed that the prologues, summaries and/or glosses were full of Lutheran 'errors'. ${ }^{37}$ It is also highly probable that the aforementioned 1525 edition of Christoffel van Ruremund was among the censured editions. From 1529 onwards, the mere possession of forbidden Bible translations was punishable by death, as was the case with other Reformation-minded literature. This sanction clearly signified a considerable hardening of attitudes when compared with earlier imperial decrees.

If we are to believe martyrologist John Foxe, however, Christoffel van Ruremund was not to die in his native country. According to the Foxe's Acts and Monuments, Van Ruremund was arrested in 1531 during one of his visits to England, accused of smuggling English New Testaments and jailed in Westminster where he died. ${ }^{38}$ His widow continued his printing business in Antwerp and continued to publish Tyndale's New Testaments. She is particularly known for having published a pirate edition with unauthorised changes by George Joye in August 1534, with a second edition in January 1535, both in sextodecimo format. All this took place to the considerable indignation of William Tyndale ... ${ }^{39}$

37. In the French version of the edict destined for the Duchy of Brabant, we read: “(...) plains d'hérésies luthéranes ou autres, et pour telz réprouvez et condempnez par la faculté des théologiens de l'université de Louvain" (Charles Laurent, Jules-Pierre-Auguste Lameere, Henri Simont [eds.], Recueil des ordonnances des Pays-Bas: Règne de Charles-Quint 1506-1555, 6 vols., Brussels 1893-1922, 2: Ch. Laurent, J. Lameere [eds.]: Contenant les ordonnances du 29 janvier 1519 au 31 décembre 1529, p. 579).

38. "Christopher, a Dutchman of Antwerp, A.D. 1531. This man, for selling certain New Testaments in English, to John Row aforesaid, was put in prison at Westminster, and there dies" (John Foxe, The Acts and Monuments of John Foxe, 11 vols., London 1853-1861, 5/1, p. 37). According to E. Gordon Duff, there can be no doubt that Christoffel van Ruremund is implied here (Duff, A Century [as in note 17], p. 140).

39. Daniell, "William Tyndale" (as in note 8), p. 47; id., The Bible in English (as in note 8), 


\section{HANS (I) VAN RUREMUND'S DUTCH BIBLE EDITIONS AND THE IMPERIAL 'BIBLE POLICY'}

Little is known about Hans (I) van Ruremund, the probable brother of Christoffel..$^{40}$ In 1525, two Dutch Bible editions left his Antwerp printing office. In the first half of 1525, Hans (I) van Ruremund printed a Dutch edition of the Old Testament in four volumes for the publisher-bookseller Peter Kaetz. ${ }^{41}$ Textual material of different origins was brought together, which made this Old Testament a typical product of the time in which 'confessionalisation' had not totally broken through. ${ }^{42}$ The first volume, including the Pentateuch, was, amongst others, based on the 1523 translation made by Luther. ${ }^{43}$ The second volume included a Dutch translation of the Psalms according to Luther's separate 1524 edition (September 29th). The books of Joshua up to and including 2 Kings, also in the second volume, were translated specifically for this edition on the basis of

p. 151; Juhász, "Catalogue n 102" (as in note 27), pp. 159-160; Verbraak, "William Tyndale" (as in note 8), pp. 171 and 180. With a reference to NK 2485 and NK 2490, to BS 1534.NT.eng.CvRwid.a and BS 1535.NT.eng.CvRwid.a, to DMRev, nos. 12 and 17, to STC, 1, nos. 2825 and 2827. STC 2833 and 2834 leaves open the possibility that two Tyndale quarto New Testaments from 1536, published under a false name, were also edited by Christoffel van Ruremund's widow (or by Mathias Crom).

40. Rouzet (ed.), Dictionnaire (as in note 9), pp. 194-195; de Bruin, Broeyer, De Statenbijbel (as in note 7), pp. 84-85; den Hollander, De Nederlandse bijbelvertalingen (as in note 7), pp. 66-68. He is referred to as Hans the first (I), the son of his brother Christoffel also bearing the name Hans is referred to as the second (II).

41. De Bruin, Broeyer, De Statenbijbel (as in note 7), pp. 91-94; den Hollander, De Nederlandse bijbelvertalingen (as in note 7), pp. 67, 314-317; Herbert Migsch, "Die Jeremia-Übersetzung in der Ruremundebibel (1525). Eine nach der Complutenser Vulgata und der ersten Rabbinerbibel revidierte Übersetzung aus der Delfter Bibel (1477)," in: Dutch Review of Church History 84 (2004), pp. 126-148.

42. F. H. Higman called this phenomenon "des emprunts trans-confessionnels" (Francis M. Higman, Bibliographie matérielle et histoire intellectuelle: les débuts de la Réforme Française. The Cassal Bequest Lecture Delivered before the University of London on 29 April 1986, London 1986, pp. 7-10).

43. The question to what extent van Ruremund has made use of an until now unkown Middle Dutch History Bible from ca. 1485 for his translation of the Pentateuch, is still the subject of research on the part of Youri Derplenter of Ghent University. Desplenter bases his research on an analysis of the Canticles and Psalms in a manuscript known as the PhiladelphiaPsalter. See Youri Desplenter, "Fund eines mittelalterlichen 'Lutherpsalters': Der mittelniederländische Philadelphia-Psalter (ca 1485) und die frühmodernen niederländischen Bibeldrucke," in: Wim François, August den Hollander (eds.), 'Wading Lambs and Swimming Elephants': The Bible for the Laity and Theologians in the Medieval and Early Modern Era, Leuven (forthcoming). 
the Vulgate, probably according to the version to be found in the 1514-17 Polyglotta Complutensis. The rest of the Old Testament, published in volumes three and four, offers a text that was based on the 1477 Dutch Delft Bible, although it was also evidently revised on the basis of the Complutensian Vulgate. ${ }^{44}$ One exception in this regard was the book of Daniel - in volume four - which was translated directly from the Vulgate. All four volumes contained prologues with textual material from various sources, thus demonstrating once again that reform-minded Catholics, Erasmian humanists and moderate Lutherans were still very close to one other in the first half of the 1520s and that the process of 'confessionalisation' had not yet reached its completion. The first prologue was entitled "Saluyt aen allen kersten menschen" [Greetings to all Christian people] and was inspired by Erasmus, in the sense that everyone was called upon to read and understand the Scriptures. On the other hand, the need for a competent explanation by the doctors of the Church was emphasised and an exposition was given on the traditional fourfold sense of the Scriptures as a means to unveil the obscurity of the Bible. The second prologue contained a short "argumentum" borrowed from Erasmus, intended as an introduction to the letter of Jerome to Paulinus of Nola, which in its turn served as a third prologue. The prefaces to the individual Bible books were mostly taken from the 1477 Delft Bible. The marginal glosses only referred to other Bible books (as was the case in the Polyglotta Complutensis). Only the Psalms were provided with glosses derived from Luther's annotations, whereas the latter's annotations to the Pentateuch were not translated into Dutch. ${ }^{45}$ The colophon to the prophet Malachi in this edition is preceded by these final words: "Hier eyndt die propheet Malachias. Hier na sal volgen dboeck der Machabeorum" [Here ends the prophet Malachi. Hereafter follows the book of the Maccabees]. Hans (I) van Ruremund, however, did not publish the book of Maccabees himself. This gap was filled by the 1525 Maccabees edition in a sextodecimo format printed by his brother Christoffel. These four or five sextodecimo format volumes of the Old Testament were in turn to be

44. Herbert Migsch has demonstrated that the book of Jeremiah as it is found in the Delft Bible had not only been revised on the basis of the Complutenser Vulgate, but also on the basis of the first rabbinical Bible, printed in 1516-1517 in Venice by Daniël Bomberg for Felix Pratensis (Migsch, "Jeremia-Übersetzung" [as in note 41], pp. 136).

45. For example: Ps 78:57: "(valsche boge) dat is gelijck een boghe dreycht ende sciet niet, also stellen hem de smeekers ende ypocriten vroom ende en is niet daer inne." Comp. Ps 78:57 [LUTH-1524]: "(falscher bogen) das ist wie eyn boge drewet und scheusst nicht, also stellen sich die heuchler frum und ist nichts dahynden und druckt nichts nach" ["(false bow) it is like a bow that threatens but does not shoot, so the petitioners and hypocrites pose as if they are devout but, inside, they are not."] 
supplemented by one of the two New Testaments in the same format Christoffel had printed in 1525 and 1526. In this manner, therefore, the entire Dutch Bible had become available in a series of pocket-books.

In the second half of 1525, Hans (I) van Ruremund also released a Dutch edition of the New Testament (without the 'epistle readings' taken from the Old Testament) onto the market in octavo format. ${ }^{46}$ This edition featured the 'standard' translation published for the first time in 1523 by Adriaen van Berghen and Doen Pietersoen, in other words a Luther translation. ${ }^{47}$ The prologue to this New Testament is entitled "Prologue. Het waer wel recht ende behoorlic (...)" [Prologue. It would be right and proper (...)] and is translated from the prologue to Luther's $1522 \mathrm{New}$ Testament. The prefaces to the Epistles and the Apocalypse are also translations of Luther's prefaces and as such are permeated with and evangelical spirit. These prologues and prefaces had also been included in other Dutch Bibles of that year (1525; e.g. those of Adriaen van Berghen and Christoffel van Ruremund). Hans (I) van Ruremund also included several interlinear glosses in the Epistles, based on those found in the 1523 Doen Pietersoen edition, which had in fact been borrowed from Luther. A few independently translated Lutheran annotations accompanied the text of the other biblical books. ${ }^{48}$ For the sake of completeness, it should be noted that Hans (I) van Ruremund's edition surpassed those of his Antwerp colleagues in 'malice'. He was one of the few printer-publishers in the Low Countries who dared to insert the re-

46. De Bruin, Broeyer, De Statenbijbel (as in note 7), pp. 84-85; den Hollander, De Nederlandse bijbelvertalingen (as in note 7), pp. 67, 221-222, 318-320.

47. Matt 3:2: "Betert u"; Matt 4:17: "Betert u"; Matt 16:18: "Ghi sijt Petrus ende op desen steen sal ick timmeren mijn gemeinte"; Rom 3:28: "So houden wi nu dat die mensche gerechtverdicht wort sonder te doen die wercken des wets alleene doer tgelove." The italized word "alleene" [alone, here only] is a typical Lutheran addition adopted by Hans (I) van Ruremund. See also Jas 5:14: "Isser yemant cranck onder u die hale die outsten vander ghemeynten ende laten over hem bidden ende salven met olye inden naem des heren."

48. Matt 3:15: "(...) op dat wi alle gerechticheyt volbrenghen moghen" (interlinear gloss: "[alle gerechticheyt] wort vervult wanneer wi alle onse gherechticheyt ende eer verlaten. Dat god alleen voor dien ghehouden wordt die gherecht is ende gherecht maect die geloovighen (...)"; trans.: "[All justice] will be fulfilled when we all leave our justice and honour. God only shall be regarded as the One who is just and justifies the faithful"); Mt 7:6 about the holy that must not be given unto the dogs (interlinear gloss: "[Dat heylichdom] is gods woort waer doer alle dinck gheheylicht wort"; "[Honden] sijn die dat woort gods vervolghen"; trans.: "[That sanctuary] is God's word by which all things become sanctified"; "[Dogs] are those who persecute the Word of God"); Rom 4:4: "Mer den genen die werct dien en wort dat loon niet gherekent uut ghenaden (...)" (interlinear gloss: "[Maer] hier bewijst hi met twee exempelen dat verdienste niet en is maer gods ghenade alleen"; trans. "[But] here he proves with two examples that it is not merit but God's grace only"). 
nowned illustrations showing the Beast of the Apocalypse emerging from the bottomless pit according to Rev 11,7 (identified from the Middle Ages onwards with the Antichrist), the false prophet - depicted as a dragon - from Rev 16,13, and the whore of Babylon from Rev 17,1-6 wearing the papal tiara. The said illustrations were borrowed from the 21 woodcuts made by Hans Holbein the Younger, which appeared for the first time in Thomas Wolff's edition of Luther's New Testament, printed in Basel in $1523 .{ }^{49}$ Apart from the editions mentioned, it seems that Hans (I) van Ruremund also printed a Low German New Testament for Peter Kaetz, which was finished on June 10th 1526. No copies of this (conjectured) edition have been preserved.

As already noted, biblical editions with Reformation-minded glosses, summaries and/or prologues, were strictly forbidden by the imperial edict of 1526 . Hans (I) van Ruremund's 1525 New Testament was, of course, also subject to the same prohibition. In that same year - 1526 - Hans (I) van Ruremund found himself in trouble with the law, although there are no indications to suggest that his problems were related to the publication of New Testaments. From this moment onwards, however, the judicial authorities refused to leave him in peace. On October 30th 1526, Claes van Lyere, the sheriff of Antwerp, exiled "Hansken van Remunde" from the city and the margraviate of Antwerp and sentenced him to make a pilgrimage "ten Heyligen Bloede" [to the Holy Blood] in Wilsnack (presently in Brandenburg) for printing Lutheran books, although no further specifications are provided. He ruled, moreover, that the printer was not permitted to return to the city unless he could show evidence of having made the pilgrimage. ${ }^{50}$ On October 29th 1526, i.e. one single day prior to this event, the Antwerp Magistrate had promulgated a "gebod" [order] aiming to curb the circulation of Lutheran writings and subjecting infringements to similar penalties as mentioned in the imperial edicts. ${ }^{51}$ On March 29th 1527, however, Hans (I) van Ruremund was able nevertheless to provide evidence of having made the imposed pilgrimage.

As noted above, the 1529 anti-heretical edict issued a ban on the biblical editions of Adriaen van Berghen, Christoffel van Ruremund and the mysterious

49. For discussion, see Nelly de Hommel-Steenbakkers, "Censorship or self-protection? Modifications in Apocalypse Illustrations in Sixteenth Century Bibles Printed in the Low Countries," in: François, den Hollander (eds.), Infant Milk (as in note 8), pp. 191-221. Cf. Philipp Schmidt, Die Illustration der Lutherbibel 1522-1700: ein Stück abendländische Kulturund Kirchengeschichte, Birsenfelden, Basel 1977, pp. 93-112, 122-127.

50. Pierre Génard (ed.), Antwerpsch Archievenblad. Bulletin des Archives d'Anvers, Antwerp n.d. [1864-1925], 7, p. 159; Fredericq (ed.), Corpus (as in note 6), 5, pp. 154-155.

51. Génard (ed.), ibid., 7, p. 158; Fredericq (ed.), Corpus (as in note 6), 5, p. 154. 


\section{UNVERKÄUFLICHE LESEPROBE}

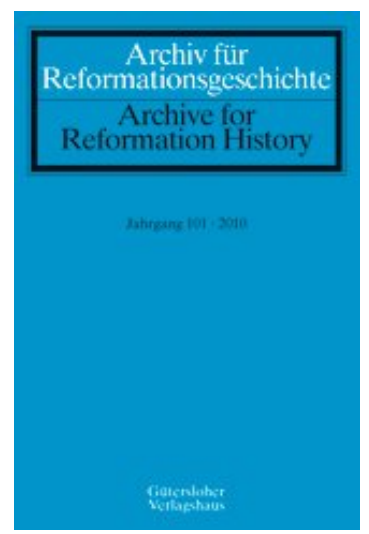

\section{Archiv für Reformationsgeschichte - Aufsatzband Jahrgang 101/2010}

Paperback, Broschur, 336 Seiten, 15,0 x 22,5 cm

ISBN: 978-3-579-08458-9

Gütersloher Verlagshaus

Erscheinungstermin: November 2010

Das Archiv für Reformationsgeschichte (ARG) ist die führende internationale Zeitschrift zur Erforschung der Reformation und ihrer Weltwirkungen. Das ARG erscheint seit 1906 und wird inzwischen gemeinsam vom Verein für Reformationsgeschichte und der Society for Reformation Research herausgegeben. Das Archiv für Reformationsgeschichte erscheint jährlich mit einem ca. 320 Seiten umfassenden Aufsatzband sowie (seit 1972) einem Beiheft Literaturbericht, das jeweils in etwa 800 kurzen Besprechungen alle wichtigen wissenschaftlichen Veröffentlichungen über die Frühe Neuzeit erfasst und kritisch vorstellt.

\section{Der Titel im Katalog}

